\title{
RESPONSE OF SOME COMMERCIAL MAIZE HYBRIDS AND THEIR PARENTS TO DOWNY MILDEW DISEASE AND YIELD LOSSES \\ Awad, H. M. F. ${ }^{1}$; M. T. Sadoma ${ }^{1}$ and M. A. M. El-Ghonemy ${ }^{2}$ \\ 1 Maize, Sugar Crops and Foliages Dis. Res. Dept. Plant Pathol. Res. Instit., A. R.C., Egypt. \\ ${ }^{2}$ Maize Res. Section, Field Crops Res. Instit., A. R.C., Egypt. \\ ABSTRACT
}

Thirty four white and yellow maize (Zea mays L.) inbred lines and hybrids were evaluated to downy mildew disease caused by Peronosclerospora sorghi (Weston and Uppal) C.G. Shaw. This study was performed in 2006 -20007 growing seasons at Gemmeiza Agricultural Research Station, El-Gharbea Governorate, Egypt. Out of the white maize genotypes, only the inbred lines Gm.22 and Gm.21were highly resistance( 0 and $0.48 \%$ disease infection, respectively). The other inbred lines showed infection types ranged from resistance (Gm.4 and Gm.30), moderate resistance (Gm.14, Gm.27 and Sd.7). Both of Gm.2 and Sd.63 showed moderate to susceptible infection types. The white hybrids (S.c.11, S.c.12, S.c.13, S.c.14 and S.c.26 ) were moderately resistant, while, hybrids S.c.21, S.c.22, S.c.27, T.w.c.321, T.w.c.325 and T.w.c326 were moderately susceptible then hybrids S.c.10, S.c.15, S.c.25, T.w.c.322 and T.w.c.327 were susceptible. It can be concluded that inbred lines $\mathrm{Gm} .4, \mathrm{Gm} .21, \mathrm{Gm} .30$ and Sd.7 play a role in conferring resistance in their hybrids and could be considered as sources of resistance to downy mildew. All the tested yellow maize inbred lines and hybrids showed moderately susceptible, and susceptible infection types. Losses in grain yield were in a parallel line with disease infection. The yellow maize genotypes scored the highest percentage of yield reduction compared with the white genotypes. All of the white inbreds and hybrids showed losses in grain yield except the inbred line Gm.22. The highest \% of grain yield losses were detected in the inbred lines Sd.63 and Gm.2 (31.19 and $21.22 \%$, respectively) as well as the hybrids S.c.10 (34.48\%), S.c.21 (31.61\%) and S.c.26 $(31.26 \%)$. Concerning with yellow maize genotypes, the highest losses \% were noticed in the inbred lines 1021 and 1002 (66.11 and 64.85\%, respectively) as well as the hybrids T.w.c. $352(87.47 \%)$, S.c. 52 (63.79\%), S.c.155 (73.77\%) then T.w.c351 $(51.93 \%)$.

Keywords: Zea mays L., Peronosclerospora sorghi, Genotypes, Hybrids, Inbred lines, Resistance. Single crosses (S.c.), Three way crosses (T.w.c.).

\section{INTRODUCTION}

Downy mildew (Peronosclerospora sp.) is considered one of the most destructive diseases of maize. In Egypt, Peronosclerospora sorghi is the important species causing downy mildew in maize and named as sorghum downy mildew. Grain sorghum (Sorghum vulgare L.) causes epidemics of downy mildew and severe losses in grain yield up to $80 \%$ depending on the growing genotypes ( Krishnappa et al., 1995). In India, a survey performed by Krishnappa, et al., 1995 in Karnataka revealed that incidence of downy mildew disease ranged from $10-90 \%$ and yield loss from $30-40 \%$ same results were obtained by Williams, 1984 ; Graig et al., 1989 ; Anahosur \& Laxman, 1991 ; Sadoma, 2003 and El-Sherbeni et al., 2008. 
Awad, H. M. F. et al.

Genetic resistance is the most efficient and has a sound way to control the disease (Kamala et al., 2002 and Barbose et al., 2005). Accordingly, breeding for resistance and using the resistant inbred lines, hybrids and cultivars are needed. Many sources for resistance have been identified and successfully used to control that disease (Yeh and Frederiksen, 1980 ; Frederiksen et al. 1986; Shivana and Anahosur, 1990 ; Olanya and Fejemisin, 1992 ; Krishnappa et al., 1995 ; Nazim et al., 1995 ; Narayana et al., 1997 ; Adipala et al., 1999; El-Moghazy, 2003 and Barbosa et al., 2005 ).

\section{MATERIALS AND METHODS}

This study was carried out in the disease nursery field of downy mildew at Gemmeiza Agricultural Research Station during 2006 and 2007 growing seasons.

\section{Sources of maize materials:}

Thirty four white and yellow maize (Zea mays L.) inbred lines and hybrids were obtained from the National Maize Programe, Field Crops Res. Instit. for evaluation against downy mildew disease ( Table 1).

Preparing the field nursery:

The field layout was prepared as follows: the highly susceptible variety of Sudan grass [ Sordan79 (Sorghum sudanens)] was sown in every third row throughout the field at least three weeks prior to planting. Also, the field was surrounded by a border of three rows planted with the same Sudan grass as spreader of the asexual spores (conidia) to obtain equal distribution of the disease inoculums throughout the field. After establishment of the disease and the appearance of the abundant conidia on leaf surfaces (3-4 weeks), the rows in-between the spreader rows were planted with maize genotypes. Plants of sudan grass were cut monthly about $20-25 \mathrm{~cm}$ above soil level for increasing the spore production needed for infection ( $\mathrm{El}$ Mersawy, 2000).

\section{Experimental design :}

Maize genotypes were divided into two groups, the first was planted in the field disease nursery of downy mildew. While the second group was planted out of the field infection after treated the seeds by Metalaxyl $\{\mathrm{N}-(2,6-$ dimethylpheny)- $\mathrm{N}$-(methoxyacetyl)-DL-alanine methyl ester\} at the rate of 3 $\mathrm{gm} / \mathrm{Kg}$ seeds. Maize genotypes were planted in a Completely Randomized Block Design with three replicates.

\section{Disease assessment :}

Infection of downy mildew disease was carried out after 45 days of sowing as disease percentage. Downy mildew disease was estimated as percentage of infected plants. Disease infection was classified according to the scale adopted by Nazim et al.(1995), as follow: highly resistant $(0-5 \%)$, resistant $(5.1-10 \%)$, moderately resistant $(10.1-20 \%)$, moderately susceptible ( $20.1-30 \%$ ), susceptible ( $30.1-50 \%$ ) and highly susceptible ( More than $50 \%$ ). Percentage of downy mildew infection ( D.M.I. \%) was calculated using the equation:

$$
\text { (D.M.I.) } \%=\frac{\text { No. of infected plants }}{\text { No. of total plants }} \times 100
$$


Yield losses assessment : 1976.

Losses of yield grain was calculated according to Calpouzos et al.,

$$
\text { Losses } \%=\frac{Y h-Y d}{Y h} \times 100
$$

Where :

$\mathrm{Yh}=$ Yield of healthy plants.

Yd $=$ Yield of disease plants.

Table (1): List of thirty four maize genotypes tested against downy mildew disease during $2006-2007$ growing seasons.

\begin{tabular}{|c|c|c|c|}
\hline \multicolumn{2}{|l|}{ White } & \multicolumn{2}{|c|}{ Yellow } \\
\hline \multirow{3}{*}{$\begin{array}{l}\text { Maize genotypes } \\
\text { Inbred lines }\end{array}$} & Pedigree & Maize genotypes & Pedigree \\
\hline & & & \\
\hline & Parent & 1001 & Parent \\
\hline $\mathrm{Gm} .4$ & " & 1002 & " \\
\hline $\mathrm{Gm} .14$ & " & 1004 & \\
\hline Gm.21 & $"$ & 1021 & \\
\hline Gm.2 & " & & \\
\hline $\begin{array}{l}\text { Gm.27 } \\
\text { Gm.30 }\end{array}$ & " & & \\
\hline Sd. 7 & $"$ & & \\
\hline $\begin{array}{l}\text { Sd.63 } \\
\text { Hybrids }\end{array}$ & & & \\
\hline $\begin{array}{l}\text { Single crosses (S.c.) } \\
\text { S.c. } 10\end{array}$ & Sd.7 X Sd. 63 & S.c.51 & $1001 x$ \\
\hline $\begin{array}{l}1004 \\
\text { S.C.11 }\end{array}$ & & & $1002 \times 1004$ \\
\hline S.c. 12 & Sd.7 X Gm.21 & S.c. 155 & $1002 \times 1021$ \\
\hline $\begin{array}{l}\text { S.c. } 13 \\
\text { S.c. } 14\end{array}$ & Gm.4XGm.30 & & \\
\hline S.c. 15 & Sd. 63 XGm.30 & & \\
\hline S.c. 21 & $\mathrm{Gm} .2 \times \mathrm{Sd} .63$ & & \\
\hline S.c.22 & Gm.21X Sd.63 & & \\
\hline $\begin{array}{l}\text { S.c. } 25 \\
\text { S. }\end{array}$ & Gm.14X Sd.63 & & \\
\hline $\begin{array}{l}\text { S.c. } 26 \\
\text { S.c. } 27\end{array}$ & $\begin{array}{l}\text { Gm.22XX Sd.63 } \\
\text { Gm } 27 X \text { Sd } 63\end{array}$ & & \\
\hline Three way crosses (T.w.c & & & \\
\hline T.w.c.321 & S.c. $21 \times$ Sd.7 & T.w.c.351 & S.c. $51 \times 1021$ \\
\hline T.w.c.322 & S.c.22 X Sd.7 & T.w.c.352 & S.c. $52 \times 1021$ \\
\hline T.w.c.325 & S.c. $25 \times$ Sd.7 & & \\
\hline $\begin{array}{l}\text { T.w.c.326 } \\
\text { T.w.c.327 }\end{array}$ & $\begin{array}{l}\text { S.C. } 26 \times \text { Sd. } 7 \\
\text { S.c. } 27 \times \text { Sd. } 7\end{array}$ & & \\
\hline
\end{tabular}

\section{RESULTS AND DISSCUSION}

Data in Table (2) reveal the response of 25 white genotypes to downy mildew disease. The genotypes showed different responses range between resistant to susceptible reactions. Out of the nine inbred lines, Sd63 showed susceptible infection type (S) with mean disease severity $32.61 \%$, while, the inbred line Gm.2 was moderately susceptible (22.08\%).

The remained lines showed reactions ranged between infection types, HR( Gm.22 and Gm.21) ; R ( Gm.4 and Gm.30); then MR (Gm.27 and Gm.14) . 
Table (2) :Response of commercial white maize inbred lines and their hybrids to downy mildew disease during $2006 / 2007$ growing seasons.

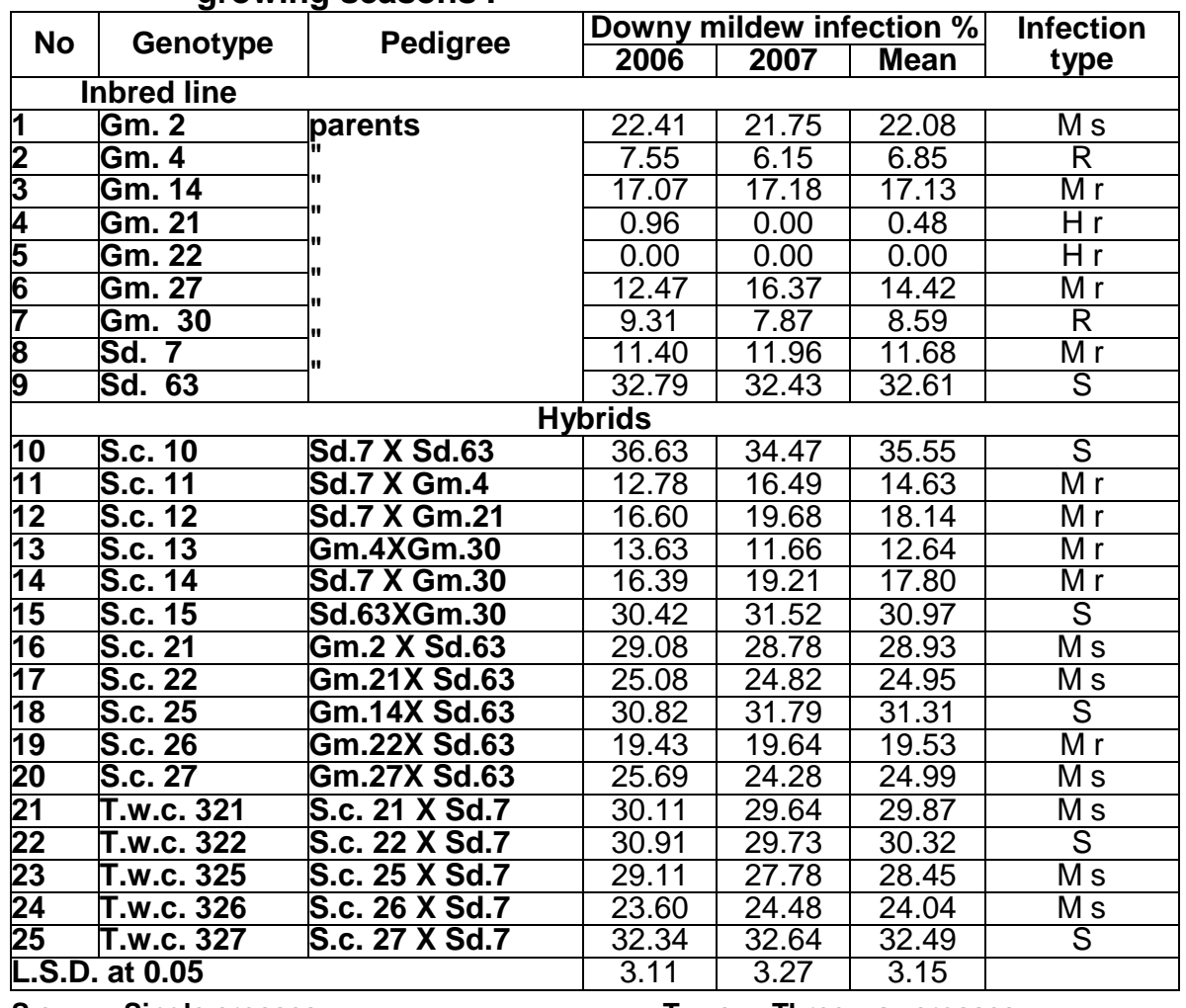

S.c. $=$ Single crosses . T.w.c. $=$ Three way crosses.

Concerning with the white hybrids, it exhibited reactions ranged between MR to $S$ infection types. Single crosses no's 11, 12,13,14, 26 showed moderate resistant reaction $(14.63,18.14,12.64,17.80$ and $19.53 \%$ disease severity, respectively). Single crosses no's 21, 22, 27 and Twc. no's , 321,325 , and 326 were moderate susceptible $(28.93,24.95,24.93,29.87$, $28.87,28.45$ and $24.04 \%$ disease severity, respectively). However, the hybrids,Sc.10, Sc.15, Sc.25, Twc.322 and Twc.327 were susceptible.

Experience has shown that the most efficient control of downy mildew on maize is through-out incorporating genetic resistance available from desirable downy mildew resistant donors. Therefore, a great attention paid the breeders to find out resistant sources to commercial varieties and hybrids (Borges, 1987; Shivanna \& Anahosur, 1990; Reedy et al., 1992 and Sadoma, 2003). The obtained results show that the white inbred lines Gm.4, Gm.30 and Sd.7 shared in conferring resistance in some hybrids i.e. Sc.11, Sc.12, Sc.13 and Sc.14. So, these lines could be considered as important sources of resistance to that disease. Similar results were obtained by Gowda et al.,1991; Nazim et al.,1995 and Adipala et al.,1999. 
Screening of local yellow maize genotypes reveal that no one of them showed resistance to downy mildew disease . It could be said that all of yellow inbred lines and hybrids maize has not any genes of resistance or susceptibility is dominance over resistance in these genotypes. Similar results were obtained by Olanya and Fejemisin (1992) they stated that 5 genotypes of maize recorded mean percentage of infection ranged from $70-$ $100 \%$.

Table (3) : Response of 4 inbred lines and 5 commercial yellow maize hybrids to downy mildew disease during 2006 and 2007 growing seasons.

\begin{tabular}{|c|c|c|c|c|c|c|}
\hline \multirow{2}{*}{ No } & \multirow{2}{*}{ Genotype } & \multirow{2}{*}{ Pedigree } & \multicolumn{3}{|c|}{ Downy mildew infection \% } & \multirow{2}{*}{$\begin{array}{l}\text { Infection } \\
\text { type }\end{array}$} \\
\hline & & & 2006 & 2007 & Mean & \\
\hline \multicolumn{7}{|c|}{ Inbred line } \\
\hline 1 & 1001 & \multirow{4}{*}{$\begin{array}{c}\text { parents } \\
" \\
" \\
"\end{array}$} & 42.21 & 42.89 & 42.55 & S \\
\hline 2 & 1002 & & 68.58 & 59.44 & 64.01 & $\mathrm{Hs}$ \\
\hline 3 & 1004 & & 22.69 & 21.40 & 22.05 & $\mathrm{M} \mathrm{s}$ \\
\hline 4 & 1021 & & 60.08 & 63.86 & 61.97 & $\mathrm{Hs}$ \\
\hline \multicolumn{7}{|c|}{ Hybrids } \\
\hline 5 & S.c. 51 & $1001 \times 1004$ & 41.42 & 46.60 & 44.01 & S \\
\hline 6 & S.c. 52 & $1002 \times 1004$ & 65.29 & 67.16 & 66.23 & $\mathrm{HS}$ \\
\hline 7 & S.c. 155 & $1002 \times 1021$ & 77.84 & 70.10 & 73.97 & $\mathrm{Hs}$ \\
\hline 8 & T.w.c. 351 & S.c. $51 X 1021$ & 54.02 & 55.00 & 54.51 & $\mathrm{Hs}$ \\
\hline 9 & T.w.c. 352 & S.c. $52 \times 1021$ & 82.85 & 80.93 & 81.89 & $\mathrm{Hs}$ \\
\hline \multicolumn{3}{|c|}{ L.S.D. at 0.05} & 6.79 & 7.87 & 7.08 & \\
\hline
\end{tabular}

M s = Moderately susceptible ( $20.1-30 \%$ infection).

$S=$ Susceptible (30.1 $-50 \%$ infection).

H s = Highly susceptible (More than $50 \%$ infection).

S.c. = Single crosses .

T.w.c. = Three way crosses

Data in table (4) clear that, differences between protected and infected white maize inbred lines and hybrids for grain yield / plot were due to differences in disease severity level which ranged from $0.48-32.61 \%$ in the inbred lines and from $12.64-35.55 \%$ in the hybrids. All of the white inbred and hybrids scored losses in grain yield except the inbred line Gm. 22, which was free from disease infection.

The highest \% of losses were detected in The inbred lines Sd.63 and Gm.2 (31.19 and 21.22\%, respectively) as well as the hybrids S.c.10 (34.48 $\%)$, S.c.21 (31.61\%) and S.c.26 (31.26\%). Whereas, The lowest percentages of losses were detected in the line Gm.4 (5.52\%) and the hybrids S.c.11 and S.c.12 (15.43 \%). Concerning with, yellow maize genotypes, the highest losses \% were noticed in the inbred lines 1021 and $1002(66.11$ and $64.85 \%$, respectively) as well as the hybrids T.w.c 352 (87.47\%), S.c.52 (63.79\%), S.c.155 (73.77\%) then T.w.c351 (51.93\%). The lowest loss \% was $40.29 \%$ in S c.51. In general, the loss \% in grain yield was run in a parallel line with infection \% of downy mildew either in white or yellow maize genotypes. 
Table (4): Combined data of yield losses of 34 white and yellow maize genotypes due to the infection with downy mildew disease in 2006 and 2007 growing seasons.

\begin{tabular}{|c|c|c|c|c|c|c|c|c|c|}
\hline \multicolumn{5}{|c|}{ White maize genotypes } & \multicolumn{5}{|c|}{ Yellow maize genotypes } \\
\hline \multirow[b]{2}{*}{ 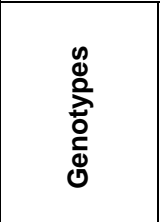 } & \multirow[b]{2}{*}{ 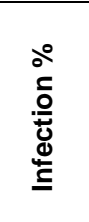 } & \multicolumn{2}{|c|}{ Yield Kg / plot } & \multirow[b]{2}{*}{ 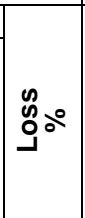 } & \multirow[b]{2}{*}{ 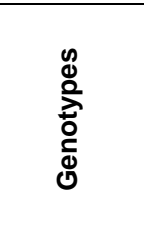 } & \multirow[b]{2}{*}{ 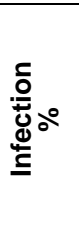 } & \multicolumn{2}{|c|}{ Yield Kg / plot } & \multirow[b]{2}{*}{ ్ㅗㅇํ } \\
\hline & & 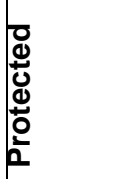 & 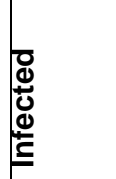 & & & & 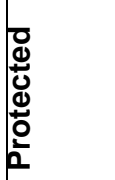 & 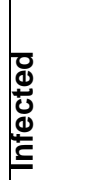 & \\
\hline \multicolumn{5}{|c|}{ Inbred line } & \multicolumn{5}{|c|}{ Inbred line } \\
\hline Gm. 2 & 22.08 & 3.110 & 2.50 & 21.22 & 1001 & 42.55 & 4560 & 2.650 & 41.89 \\
\hline Gm. 4 & 6.85 & 3.170 & 2.990 & 5.52 & 1002 & 64.01 & 4.780 & 1.680 & 64.85 \\
\hline Gm. 14 & 17.13 & 3.970 & 3.270 & 17.93 & 1004 & 22.05 & 5.520 & 4.250 & 23.01 \\
\hline Gm. 21 & 0.48 & 3.480 & 3.34 & 4.17 & 1021 & 61.97 & 4.190 & 1.420 & 66.11 \\
\hline Gm. 22 & 0.00 & 3.200 & 3.200 & 0.00 & & & & & \\
\hline Gm. 27 & 14.42 & 3.700 & 3.170 & 14.46 & & & & & \\
\hline Gm. 30 & 8.59 & 3.330 & 3.080 & 7.80 & & & & & \\
\hline Sd. 7 & 11.68 & 2.550 & 2.250 & 11.77 & & & & & \\
\hline Sd. 63 & 32.61 & 3.950 & 2.830 & 31.19 & & & & & \\
\hline \multicolumn{5}{|l|}{ Hybrids } & \multicolumn{5}{|l|}{ Hybrids } \\
\hline S.c. 10 & 35.55 & 11.580 & 7.550 & 4.48 & S.c. 51 & 44.01 & 12.320 & 7.300 & 40.75 \\
\hline S.c. 11 & 14.63 & 10.420 & 8.790 & 15.43 & S.c. 52 & 66.23 & 12.870 & 4.660 & 63.79 \\
\hline S.c. 12 & 14.63 & 10.420 & 8.790 & 15.43 & S.c. 155 & 74.05 & 15.530 & 4.080 & 73.77 \\
\hline S.c. 13 & 18.14 & 12.420 & 10.200 & 17.87 & T.w.c. 351 & 54.51 & 12.670 & 6.090 & 51.93 \\
\hline S.c. 14 & 12.64 & 11.930 & 10.230 & 12.99 & T.w.c. 352 & 81.95 & 12.210 & 1.530 & 87.47 \\
\hline S.c. 15 & 17.80 & 13.540 & 11.50 & 16.93 & & & & & \\
\hline S.c. 21 & 30.97 & 13.150 & 8.830 & 31.16 & & & & & \\
\hline S.c. 22 & 28.93 & 12.670 & 9.000 & 28.94 & & & & & \\
\hline S.c. 25 & 24.95 & 11.210 & 8.480 & 24.40 & & & & & \\
\hline S.c. 26 & 31.31 & 13.170 & 9.020 & 31.52 & & & & & \\
\hline S.c. 27 & 19.53 & 11.800 & 9.480 & 19.66 & & & & & \\
\hline T.w.c. 321 & 24.99 & 12.130 & 9.080 & 25.07 & & & & & \\
\hline T.w.c. 322 & 29.87 & 16.040 & 11.180 & 28.84 & & & & & \\
\hline T.w.C. 325 & 30.32 & 15.080 & 10.580 & 29.83 & & & & & \\
\hline T.W.C. 326 & 28.45 & 13.750 & 9.820 & 28.45 & & & & & \\
\hline T.w.C. 327 & 24.04 & 11.150 & 8.530 & 23.45 & & & & & \\
\hline LSD at 0.05 & 3.15 & 0.54 & 0.42 & - & & 7.08 & 0.64 & 0.53 & - \\
\hline
\end{tabular}

Anahosur and Laxman (1991) stated that the greatest loss in grain yield was recorded in genotype DMS-652 (78.5\%), while the lowest loss was in genotype CSV-4 (9.6\%). Also, Mendez et al., (1990) found that the genotype FS-25A recorded grain yield $3.51 \mathrm{t}$./ha. as a result to high infection $(16.1 \%)$ and was less than the genotype ATx-623 who scored disease infection $14.9 \%$ and grain yield 3.84 t./ha. In India, a survey performed by Krishnappa et al., (1995) in Karnataka revealed that incidence of downy mildew disease ranged from $10-90 \%$ and yiel loss from $30-40 \%$. Similar results were obtained by (Williams, 1984 ; Graig et al., 1989 ; Anahosur \& Laxman, 1991 ; Sadoma, 2002 and El-Sherbeni et al., 2008 ) .

\section{REFERENCES}

Adipala, E. ; Bigirwa, G. ; Esele, J.P. and Cardwell, K.F. 1999. Development of sorghum downy mildew on sequential plantings of maize in Uganda. International J. of Pest Management. 45 (2): 147-153. 
Anahosur, K.H. and Laxman, M.L. 1991. Estimation of loss in grain yield in sorghum genotypes due to downy mildew. Indian phytopathol. 44 (4): 520-522.

Barbose,F.C.R. ; Casela,C.R. ; Pfenning,L.H. and Santos,F.G. 2005. Identification of sources of resistance in sorghum to Peronosclerospora sorghi . Fitopathologia Brasilerira 30 (5) : 522-524.

Borges, F.O.L., 1987. Diallel analysis of maize resistance to sorghum downy mildew. Crop. Science. 27 (2): 178-180.

Calpouzos, L. ; Roellfs ME. Mdson, A. P. ; Maetin, R.B. ; Welsh, J.R. and Wilcoxone, R.D. 1976. A new model measures yield losses caused by stem rust in spring wheat. Agric. Exp. Sta. Univ. Minnesota Tech. Bull. $307: 1-3$.

El-Mersawy, E.M. 2000. Biological control of maize downy mildew disease caused by Peronosclerospora sorghi, in Egypt. J. Agric. Sci., Mansoura Univ. 25 (11): 6788-6794.

El-Moghazy, S.M.Y. 2003. Studies on the integrated control of downy mildew disease of maize and sorghum . Ph. D. Thesis, fac. Agric. Kafr ElSheikh, Tanta Univ. 128 pp.

El-Sherbeni , A. E.; El-Zahaby, H. M. ; Kisgk, A. A. ; Awad, H. M. F. and Aml El-Shehawy, E. A. 2008. Biochemical changes due to downy mildew disease resistance caused by Peronosclerospora sorghi in some Egyption grain sorghum cultivare. The first International Conference on Environmental Studies and Research ( Natural Resources \& Sustainable Development), Environmental Studies and Research Institute ( ESRI), Minufiya Univ. Sadat Branch, Egypt, 7-9 April , pp. 1018.

Frederiksen, R.A.; Rosenow, D.T. ; Collins, D. and Craig, J. 1986. Registration of six bulks of downy mildew resistant sorghum germplasm. Crop. Science.26 (1) : 208-209.

Graig, J. ; Odvody, G. N. ; Wall, G. C. and Meckerstock, D. H. 1989. Sorghum downy mildew loss assessment with nearisogeneic sorghum population. Phytopathology 79 (4) : 448-451.

Gowda, K.T.P. ; Gowda, B.J. and Rajasekharaiah, S., 1991. Assessment of stages of artificial inoculation to evaluate different maturity groups of maize genotypes against downy mildew. Current Research University of Agriculture Sciences Bangalor. 20 (5): 84-85.

Kamala, V. ; Singh, S.D. ; Brame, P.J. and Manohar Rao, D. 2002. Sources of resistance to downy mildew in wild and weed sorghums. Crop Sci.42: 1357-1360.

Krishnappa, M. ; Naidu, B.S. and Seetharam, A. 1995. Inheritance of resistance to downy mildew in maize. Crop Improvement. 22 (1): 33-37.

Mendez, A.V. ; Heppertiy, P. ; Santiago, E. and Juarbe, N. 1990. Performance of two forage sorghum hybrids in southwest Puerto Rico. Journal of Agriculture of the University of Puerto Rico. 74 (1): 1-13 .

Narayana, Y.D. ; Bandyopadhyay, R. ; Pande, S. ; Mathur, K. and Shetty, H.S. 1997. Evaluation of sorghum lines for multiple disease resistance in India. J. of Mycology and Plant Pathology. 27 (3): 271-274. 
Nazim,M. ; Khalifa,E.Z. ; El-Mersawy,E.M. ; Sadoma,M.T. 1995. Downy mildew on maize in Egypt. Egypt. J. Phytopathol. 23 (1-2) : 53-67.

Olanya, O.M. and Fejemisin, J.M. 1992. Remission of symptoms on maize plants infected with downy mildew in northern Nigeria. Plant Disease. $76(7): 753$

Reedy, B.V.S. ; Mughogho, L.K. ; Narayana, Y.D. ; Nicodemus, K.D. and Stenhouse, J.W., 1992. Inheritance pattern of downy mildew resistance in advanced generations of sorghum. Annals of Applied Biology. 121(2): 249-255.

Sadoma, M.T. 2003. Further studies on downy mildew disease of maize in Egypt. Ph.D. Thesis .Fac. Agri. Minufiya Univ., 154 pp.

Shivana, H. and Anahosur, K.H. 1990. Breeding downy mildew resistance sorghum varieties. Indian Phytopathol. $43: 372-374$.

Williams, N.K. 1984. Downy mildew of tropical cereals. Advances In Plant Pathology. $3: 1-103$.

Yeh, Y. and Frederiksen, R.A. 1980. Sorghum downy mildew: biology of systemic infection by conidia and of a resistant response in sorghum. Phytopathology 70 (5) : 372-376.

\footnotetext{
استجابة بعض هجن الذرة الثـامية وآبائها لمرض البيـاض الزغبس والخسـارة في

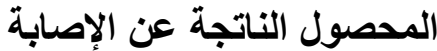

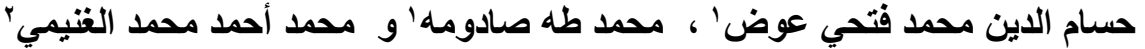

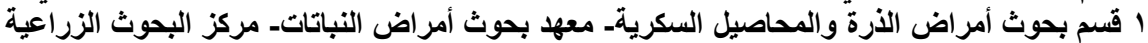

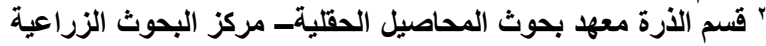

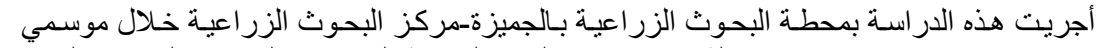

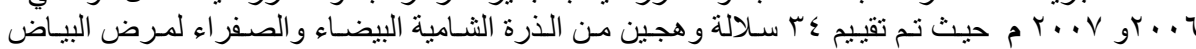

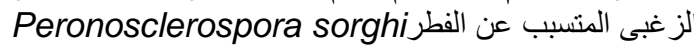

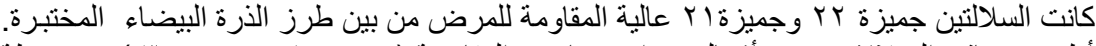

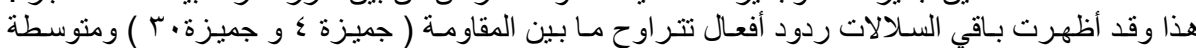

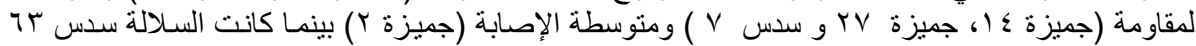

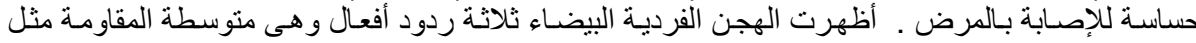

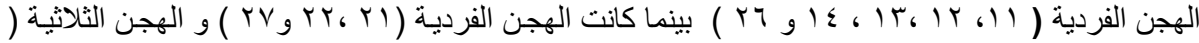

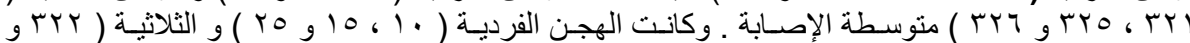

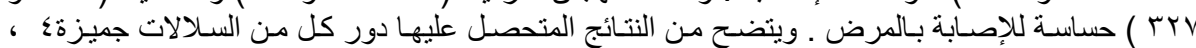

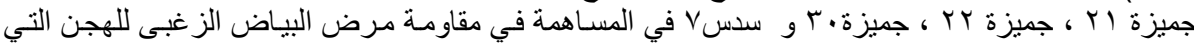

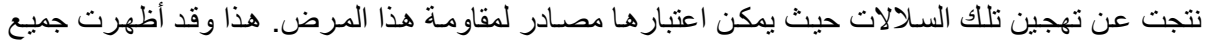

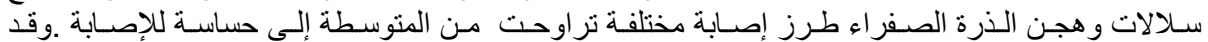

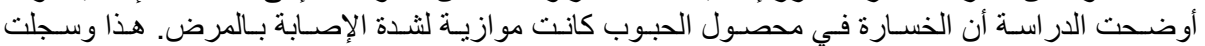

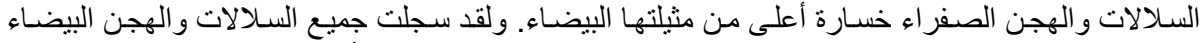

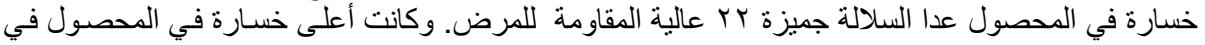

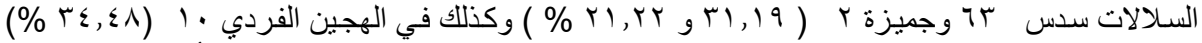

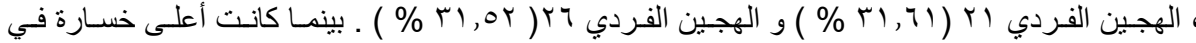

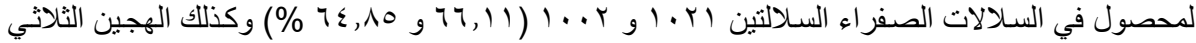

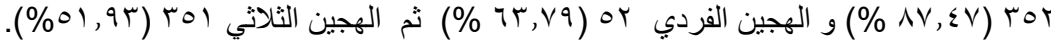

